\title{
Anthropology, Health and Illness: an Introduction to the Concept of Culture Applied to the Health Sciences
}

\author{
Esther Jean Langdon ${ }^{1}$ \\ Flávio Braune Wiik²
}

This article presents a reflection as to how notions and behavior related to the processes of health and illness are an integral part of the culture of the social group in which they occur. It is argued that medical and health care systems are cultural systems consonant with the groups and social realities that produce them. Such a comprehension is fundamental for the health care professional training.

Descriptors: Culture; Anthropology; Health Care; Health Sciences.

\footnotetext{
${ }^{1}$ Anthropologist, Ph.D. in Anthropology, Full Professor, Universidade Federal de Santa Catarina, SC, Brazil. Email: estherjeanbr@gmail.com.

2 Social Scientist, Ph.D. in Anthropology, Adjunct Professor, Universidade Estadual de Londrina, PR, Brazil. Email: flaviowiik@gmail.com.
} 


\section{Antropologia, saúde e doença: uma introdução ao conceito de cultura aplicado às ciências da saúde}

O objetivo deste artigo foi apresentar uma reflexão de como as noções e comportamentos ligados aos processos de saúde e de doença integram a cultura de grupos sociais onde os mesmos ocorrem. Argumenta-se que os sistemas médicos de atenção à saúde, assim como as respostas dadas às doenças, são sistemas culturais, consonantes com os grupos e realidades sociais que os produzem. A compreensão dessa relação se mostra fundamental para a formação do profissional da saúde.

Descritores: Cultura; Antropologia; Atenção à Saúde; Ciências da Saúde.

\section{Antropología, salud y enfermedad: una introducción al concepto de cultura aplicado a las ciencias de la salud}

Este artículo presenta una reflexión acerca de como las nociones y comportamientos asociados a los procesos de salud y enfermedad están integrados a la cultura de los grupos sociales en los que estos procesos ocurren. Se argumenta que los sistemas médicos de atención a la salud, así como las respuestas dadas a la enfermedad son sistemas culturales que están en consonancia con los grupos y las realidades sociales que los producen. Comprender esta relación es crucial para la formación de profesionales en el área de la salud.

Descriptores: Cultura; Antropología; Atención a la Salud; Ciencias de la Salud.

\section{Introduction}

Perhaps it seems out of place to address the theme of culture in a journal dedicated to the Health Sciences or to argue that the concept of culture can be useful for professionals of this area. Everyone has a common sense idea of what "culture" means. We say that a person "has culture" when he or she has a higher education, comes from a family of a good socio-economic level or understands the arts and philosophy. It is normal to consider that a "good patient" "has culture" sufficiently to comprehend and follow correctly the instructions and warnings given by the health professional. This patient is contrasted with the one "without culture", the more "difficult" patient who acts incorrectly through "ignorance" or who is guided by "superstitions".

In this article, we will discuss another notion of culture, the analytical concept that is fundamental to anthropology. Culture, as conceived by anthropology, also serves as an instrumental concept for health professionals conducting research or health intervention among rural or indigenous populations, as well as in urban contexts characterized by patients belonging to different social classes, religions, regions or ethnic groups. These patients present unique behaviors and thoughts with regard to the experience of illness, as well as particular notions about health and therapeutic practices. These particularities do not come from biological differences, but from those that are social and cultural in nature. In short, our point of departure is that everyone has culture and that it is essentially culture that determines these particularities. Moreover, questions related to the processes of health and illness should be considered from the perspective of the specific socio-cultural contexts in which they occur.

This assumption about the role of culture is not exclusive to anthropological knowledge, and theorists, researchers and professionals in the health fields - particularly those in medicine and nursing - have embraced it since the second half of the $1960 \mathrm{~s}^{(1-2)}$. They support the idea that biomedicine is a cultural system and that the realities of clinical practice should be analyzed from a transcultural perspective. Likewise, they draw attention to the relevance of the use of qualitative methods and techniques in health research, in particular, the ethnographic method ${ }^{(3)}$. Conjoined to these reflections, are theoretical and philosophical premises found at the intersection of health and culture, between the imponderables observed in practical intervention by health professionals in the face of cultural theory, between cultural relativism and universal human rights, and between the demands of a health profession and the 
more theoretical and reflexive space of anthropology ${ }^{(4)}$.

This theme has been addressed in the Latin American Journal of Nursing through publication of results of studies and research conducted by health professionals and academics ${ }^{(5-7)}$. Using the ethnographic method and interpretive analysis, these studies point out that the patient's construction of the meaning of illness is central and which is superimposed upon that of biomedical causality and rationality. For example, in a study conducted with oncological patients, it was observed that the symbolism of radiotherapy from the patients' perspective and constructed throughout the treatment process, proved to be a powerful organizer and arranger of the patient's experience against disruptions caused by the disease and its therapy. Likewise, the influence of religious belief has been observed to positively affect the survival of total laryngectomy patients who are surrounded by socio-affective religious networks accompanying them and praying for their healing. On the other hand, these studies call attention to the challenges and paradoxes inherent in the ethnographic method that require simultaneously the researcher's immersion in the quotidian socio-cultural universe of the group (of patients) to be investigated and distancing so that the investigator does not assume ethnocentric postures. They also question the factibility between the use of interpretivism, which tends toward hermeneutic subjectivity, and the construction of knowledge according to scientific objectivity.

\section{An instrumental concept of culture}

The universe that encompasses the conceptual definition of culture is extremely complex and diverse, the common divisor of anthropology's various analyticaltheoretical currents and fomenter of their epistemological and methodological approaches ${ }^{(8-9)}$. Considering the purpose of this article, we will limit ourselves to discussing some essential and instrumental aspects linked to the concept of culture, which, in turn, will be used in the typological and analytical construction proposed.

Culture can be defined as a set of elements that mediates and qualifies any physical or mental activity that is not determined by biology and which is shared by different members of a social group. They are elements with which social actors construct meanings for concrete and temporal social interaction, as well as sustain existing social forms, institutions and their operating models. Culture includes values, symbols, norms and practices.
From this definition, three aspects should be emphasized so that we can comprehend the meaning of socio-cultural activity. Culture is learned, shared, and patterned $^{(10)}$. In affirming that culture is learned, we are stating that we cannot explain the differences in human behavior through biology in an isolated way. Without denying its important role, the cultural(ist) perspective argues that culture shapes biological and bodily needs and characteristics. Thus, biology provides a backdrop for behavior, as well as for the potentialities of human formation and development. However, it is the culture shared by individuals of a society that transforms these potentialities into specific, differentiated, and symbolically intelligible and communicable activities.

Based on this assumption, being a man or woman, a Brazilian or a Chinese does not depend on one's respective genetic composition, but on how that person, through and because of culture, will behave or think. Ethnographic studies on sexual behavior patterns according to gender have indicated that there are wide variations in the behavior of the sexes and that these variations are based on what people have learned from their culture about what it is to be a man or a woman ${ }^{(11-12)}$.

Culture is shared and patterned, because it is a human creation shared by specific social groups. Material forms, as well as their symbolic content and attributions, are patterned by concrete social interactions of individuals. Culture is a result of their experiences in determined contexts and specific spaces, which can be transformed, shared and permeated by different social segments. Although the content and forms inherent in each culture can be understood and replicated individually - conferring to the culture the character of internalized and embodied personal experience - the concerns of anthropology are i) to identify cultural patterns shared by groups of individuals; ii) to deduce what is common in the actions, allocation of meaning, and significance and symbolism projected by the individuals on the material and "natural" world; iii) to reflect on the experience of living in society, including of that of becoming sick and caring for one's health, as a highly intersubjective and relational experience, mediated by the cultural phenomenon.

In order to illustrate our argument, we can observe different cultural patterns regarding the types of food and diet. In Brazil, the combination of rice and beans is fundamental for a meal to be considered complete. Without them, even with presence of meat, many say their hunger is not satisfied. Others always need a meat dish to feel well fed. They can even leave the table 
hungry, after eating a hearty dish of Chinese food filled with mixed vegetables with little meat. But a Chinese feels completely satisfied with a primarily vegetarian meal.

Not only is what to eat determined in a particular way by culture, but also when to eat as well. Most Brazilians eat the largest meal of the day at noon to "digest the food well" and to be "well-fed for work" until the late afternoon. It is common to claim that eating a lot at night, especially eating "heavy food" is bad for the stomach. In turn, North Americans, who do not miss rice and beans, generally eat less at noon and a large quantity of "heavy" food (in the eyes of the Brazilians) in the evening before sleeping. For them, food in abundance at noon is inappropriate and hinders the afternoon's work. From this perspective, culture defines social standards regarding what and when to eat, as well as the relationship between types of foods that should or should not be combined, and, consequently, the experience of satisfying hunger, or not, is both socially and biologically determined. It is biology's task to indicate basic nutritional needs and to determine the limitations of foods considered toxic.

In affirming that culture is tied to all physical or mental activity, we are not alluding to a patchwork quilt composed of pieces of superstitions or behavior lacking in intrinsic coherence and logic. Fundamentally, culture organizes the world of each social group according to its own logic. It is an integrating experience, holistic and totalizing, one of belonging and interacting. Consequently, culture shapes and maintains social groups that share, communicate and replicate their ways, institutions, and their principles and cultural values.

Given its dynamic nature and intrinsic politicoideological characteristics, culture and the elements that comprise it are mediating sources of social transformation, highly politicized, appropriated, modified and manipulated by social groups throughout their history, guided by the intentions of the social actors in the establishing of new socio-cultural patterns and societal models.

Moreover, each group interacts with a specific physical environment, and culture defines how to survive in this environment. Due to the creative and transformative character, inherent in human cultures, in interaction with the natural world, we find the existence of various different solutions for societies' survival within the similar environments. Human beings have the capacity to participate in any culture, to learn any language, and to perform any task. However, it is the specific culture into which they are born and/or raised that determines the language(s) they will speak, the activities they will develop, and their position and potential for social mobility in the social structure. Language, social roles and positions are governed by age, sex and other cultural variables that influence the bodily techniques and aesthetic patterns adopted, as well as the social roles performed according to ideal types informed by the kinship system and other institutions of the society to which a person belongs. Finally, in this dialogue between the individual and society, culture is both the subject and object. This happens, because throughout a lifetime, individuals are gradually socialized by/in the cultural patterns current in their society and which are constructed through daily social interaction, as well as through ritual processes and institutional affiliations. They are responsible for the transformation of individuals into social actors, into members of a certain group that mutually recognize each other. As social actors, they learn and replicate the principles that guide ideal patterns of valued and qualified types of action, those of behavior, dress, or eating habits, as well as techniques for diagnosis and treatment of illness. Moreover, the socialization of individuals is responsible for the transmission of meanings about why to do it.

The why to do has special importance as it allows us to understand the integration and the logic of a culture. Culture, above all, offers us a view of the world, that is, the perception of how the world is organized and how to act accordingly in a world that receives its meaning and value through culture. Thus, as previously discussed, it is the culture of a group that provides social actors with a classification and value system of those foods considered edible or not, defines the techniques and environments for obtaining food, and classifies, organizes and assigns values to various types of food, such as "good", "weak", "strong", "light"(13).

To present another example: the concept of cleanliness and hygiene are fundamental categories present in all cultures. Every culture establishes its categories of things, classifying them as "clean and pure" or "dirty and impure"(14), as well as determines which practices and knowledge are associated with these categories that contribute to their maintenance, classification and distinctions. However, the definitions about what is considered "clean" or "dirty", "pure" or "impure" are as varied as the multiplicity of human cultures found in the world. This variation reflects a fundamental assertion in the construction of the field of anthropological knowledge: the paradoxical 
confirmation of the diversity and unity encompassed by cultural phenomenon that is, at the same time, one and universal, diverse and specific.

Among the Barasana Indians of the Colombian Amazon jungle ${ }^{(15)}$, apart from ants with cassava (manioc bread), the diet consists of meat or fish obtained by the men and eaten with cassava made by the women. When a hunter is lucky, upon returning to the longhouse, he delivers the largest portion of meat to the most senior man of his extended family. His wife or wives cook the meat in a large pot and put it on the floor in the center of the house. Then, the senior man first calls the men to eat according to hierarchical rules based on age groups and prestige. Afterwards, he calls the women, though not always all of them. Children are never called to eat when the pot contains the meat of large animals or fish.

In addition to the social rules based on hierarchy and distribution of power that regulate food consumption, all foods and those who prepare or ingest them, are regulated by cultural principles of cleanliness and purity, known by the Barasana as witsioga. Witsioga consists of a substance present in the food, especially meat, which is dangerous for small children and people of certain age groups or in liminal states, such as those entering puberty or participating in shamanism initiation, pregnant or women in post-partum, and those who are ill. Since manioc bread is considered a "pure" food, that which has been touched by the hand of a person eating meat is contaminated it for those in liminal states.

The Barasana have a complex classification of animals and fish that are witsioga. They classify them according to size, behavior, etc. There are also principles that regulate a series of practices and actions that can and cannot be performed after eating meat, besides the hygienic practices intended to cleanse this substance from the people who eat meat that contains witsioga. Witsioga also regulates the diagnosis, origin and etiology of diseases, and, in turn, is linked to the cosmology of the Indians. The world is controlled by beings ("spirits") and witsioga attracts evil spirits that attack people who are classified as weak or vulnerable.

This example illustrates that when we are faced with the customs present in other cultures, we should try to understand their why. By doing this, we avoid an ethnocentric comprehension of them, that is, judging Barasana culture according to our own values and classification of the world and not according to theirs. The fact that they eat ants, eat from the same pot, eat with their hands scooping up food with pieces of manioc bread, and share a single gourd for drinking, might cause a certain repulsion, since "ants are not food" and "eating food from a pot on the floor is dirty". Also, one might consider the category witsioga to be "superstition" since such behavior is opposed to what we comprehend to be "healthy" and "clean" according to biomedical rationality.

The anthropological perspective requires that, when faced with different cultures, we do not make moral judgments based on our own cultural system and that we understand other cultures according to their own values and knowledge - which express a particular view of the world that orients their practices, knowledge and attitudes. This procedure is called cultural relativism. It is what allows us to comprehend the why of the activities and the logic of meanings attributed to them, without ranking or judging them, but only, and, above all, recognizing them as different!

Many other examples could also be drawn from ethnographic research conducted by the health professionals cited in this article(4-7). All of them lead us to reflect on issues related to health habits, rituals, techniques of care and attention, and restrictions with regard to the use of therapeutic practices (e.g. blood transfusion, organ transplantation or even abortion); all of these are mediated by cultural systems distant from, or even opposed to, the cultural standards which underlie the construction of the biomedical system and with which health professionals are trained.

We have used examples taken from a society whose culture is very distant, one characterized as a simple society. However, in a complex society like Brazil, which, in addition to being stratified by social classes, is comprised of numerous ethnic groups and population segments exhibiting diverse religious and regional customs, we find internal cultural differences and intergroup variations. Although these groups share aspects of a general culture, identified as the so-called "Brazilian culture", but we must recognize that these collectivities that make up the Brazilian population have different views of the world and perceive reality in a diverse ways, generating a complex and intertwined sociocultural mosaic. This complexity is the background of the context that articulates health, culture and society, and in which professionals and researchers in the field of health are inserted.

\section{Culture, society and health}

If we accept that culture is a total phenomenon and thus one which provides a world view for those 
who share it, guiding their knowledge, practices and attitudes, it is necessary to recognize that the processes of health and illness are contained within this world view and social praxis.

Concerns with illness and health are universal in human life and present in all societies. Each group organizes itself collectively - through material means, thought and cultural elements - to comprehend and develop techniques in response to experiences or episodes of illness and misfortune, whether individual or collective. As a consequence, each and all societies develop knowledge, practices and specific institutions that may be called the health care system ${ }^{(1)}$.

The health care system comprises all components present in a society related to health, including knowledge about the origins, causes and treatments of disease, therapeutic techniques, its practitioners, and the roles, standards and agents in interaction in this "scenario". Added to these are power relationships and institutions dedicated to the maintenance or restoration of "the state of health". This system is supported by schemes of symbols that are expressed through the practices, interactions and institutions; all are consistent with the general culture of the group, which in turn, serves to define, classify and explain the phenomena perceived and classified as "illness".

Thus the health care system is not disconnected from other general aspects of culture, just as a social system is not dissociated from the social organization of a group. Consequently, the manner by which a particular social group thinks and organizes itself to maintain health and face episodes of illness, is not dissociated from the world view and general experience that it has with respect to the other aspects and socio-culturally informed dimensions of experience. Comprehension of this totality makes it possible to apprehend the knowledge and practices linked to the health of the individuals that form a society's cultural system and intellectual and moral heritage. Thus, if we do not know that the Barasana category of witsioga is linked to their cosmology, to the classification of food and to the state/status of the people, we do not comprehend the importance given by them to the ways taken as correct and "pure" for the preparation and consumption of food. It would also be difficult to comprehend the importance of this concept within their concerns for health or to convince them that in an environment with few sources of protein, prohibiting meat for young children and breastfeeding women may affect their growth if they do not have another adequate protein source.
A health care system is a conceptual and analytical model, not a reality itself, for the understanding of social groups with whom we live or study. The concept helps to systematize and comprehend the complex set of elements and factors experienced in daily life in a fragmented and subjective manner, be this in our own society and culture or in that of an unfamiliar one.

It is important to understand that in a complex society such as the Brazilian one, there are several health care systems operating concurrently, systems that represent the diversity of the groups and cultures that constitute the society. Although the state medical system, which provides health services through the National Health System (SUS), is based on biomedical principles and values, the population, when sick, uses many other systems. Many groups do not seek medical doctors, but use folk medicine; others use medicalreligious systems, and others seek multiple alternative health systems throughout the therapeutic process. To think of the health care system as a cultural system helps us to comprehend this multiplicity of therapeutic itineraries.

\section{The Cultural System of Health}

The cultural system of health emphasizes the symbolic dimension of the understanding of health and includes the knowledge, perceptions and cognitions used to define, classify, perceive and explain disease. Each and all cultures possess concepts of what it is to be sick or healthy. They also have disease classifications, and these are organized according to criteria of symptoms, severity, etc. Their classification, as well as the concepts of health and illness, are not universal and rarely reflect the biomedical definitions. For example, in Brazil, and mau olhado (evil eye)(16) are folk illnesses that deny biomedical diagnosis and treatment. These diseases are classified according to their particular symptoms and causes that guide their diagnosis and therapeutic practices chosen. Only folk specialists have the knowledge to diagnose and treat them.

In this way, culture provides etiological theories based on the worldview of a group, and these theories can frequently indicate multiple causes for an illness episode, and they can be thought of as "mystical" and/ or "non-mystical". Among the "non-mystical", or natural causes, we find theories and perceptions about the body that attribute its poor functioning to the ingestion of certain inadequate foods, climate, social relationships or work conditions. These theories, in turn, provide a basis for preventive medicine linked to behavior and 
hygiene, as well as to elements linked to a curative medicine. The "mystical" causes frequently combine with the "non-mystical" and may indicate the need for more than one type of treatment, for example: one to heal the physical body and another to heal the spiritual or social body ${ }^{(17)}$. Etiological theories that include "natural causes" are accompanied by treatments based on knowledge of herbs and techniques of body manipulation to treat bodily symptoms. Ignorance or negation of their efficacy demonstrates the bioscientific ethnocentrism often present when evaluating other cultural systems of health care.

\section{The Social System of Health}

The system of health care is both a cultural system and a social system of health. The social system of health is composed of its institutions, organization of the health specialists' roles, rules of interaction, as well as power relationships inherent to it. Commonly, this dimension of the system of health care also includes specialists not recognized by biomedicine, such as folk healers (massage therapists, benzedeiras, curandeiros) or religious and faith healers (pastors, priests, benzedeiras, shamans, spiritists, and others), shaman, pajés, pais-de-santo).

In the world of each social group, experts have a special role to perform concerning the treatment of illness, and patients have certain expectations about how this role will be developed, which illnesses the specialist can cure, as well as a general idea about the therapeutic methods he will employ.

In complex societies, besides the traditional specialists mentioned above, we also find practitioners of Chinese and Oriental medicine. In the last ten years we have also seen a growing demand for practitioners and therapists belonging to what has been called the "new age"(18). Within the same city, there are specialists practicing several alternative therapeutic methods (reflecting different cultural systems of health care), which are selected or rejected according to factors such as religion, economic conditions, family experience and social networks, as well as other political and/or legal factors (such as the persecution by the State of a given nonofficial therapeutic practice) $)^{(16)}$.

\section{Studies in Health, Culture and Society in Brazil}

In Brazil, studies and research on health, culture and society have multiplied significantly in the last twenty years ${ }^{(19)}$. In the last decade, Anthropology of Health has been consolidated as a space for reflection and for academic and professional training of doctors, nurses and other professionals in the Area of the Health of the country ${ }^{(19)}$. There are interdisciplinary university centers and research groups involving anthropologists and researchers and intellectuals of collective and public health, dedicated to the investigation of cultural, social and politico-economic aspects linked to health issues ${ }^{(19)}$. Some publication collections have discussed the experience of sickness and the sick body in light of issues such as gender, religion, representations of healing and illness narratives(20-21). Recent ethnographies describing medical contexts, such as hospitals or clinics, have been published(22-23). The Editor of the Foundation Oswaldo Cruz (FIOCRUZ) has published the Anthropology and Health Collection since the mid-1990s, whose volumes have contributed to the dissemination of production originating from research centers and national graduate programs directed toward the area of health. Reports in Public Health, also published by FIOCRUZ, has produced a large number of articles focused on contemporary health issues, such as STD/AIDS, structure and functioning of health services, evaluation of health policies and indigenous health.

\section{Conclusions}

Although subject to internal contradictions and, consequently, potential sources of predicaments, the values, knowledge and cultural behavior linked to health form a socio-cultural system which is integrated, holistic and logical. Therefore, issues relating to health and sickness cannot be analyzed in isolation from other dimensions of social life that are mediated and permeated by cultural meaning. Health care systems are cultural systems, compatible with human groups and their social, political and economic realities that produce and replicate them. Accordingly, for theoretical and analytical purposes, the biomedical system of health care should also be considered a cultural system, as any other ethnomedical system. Therefore, interpretations of and interventions in health and illness processes - be they observed for individuals-patients or for biomedically trained health professionals - must be analyzed and evaluated using the concept of cultural relativism, thus avoiding, ethnocentric attitudes and analysis by these professionals and theorists.

In the end, we are all subjects of culture and experience it in several ways, including when we become sick and seek treatment. However, when we act as professionals and researchers from the Area of Health, we encounter cultural systems different from our own (or in which we have been trained), without applying 
relativism to our own medical knowledge. This happens, especially in the health field, because in the modern and rational West, we naturalize the medical field, attributing to it universal and absolute truth, distancing it from culturalized forms of knowledge, where truth is particular, relative and conditional.

\section{References}

1. Kleinman A. Patients and healers in the context of culture. Berkeley (CA): University of California Press; 1980.

2. Leininger MM, organizadora. Qualitative research methods in nursing. Orlando (FL): Grune \& Stratton; 1984.

3. Clammer J. Approaches to ethnographic research. In: Ellen $\mathrm{RF}$, organizadora. Ethnographic research. Londres: Academic Press; 1984. p. 57-72.

4. Leininger MM, organizadora. Culture care, diversity and universality: A theory of nursing. New York (NY): National League for Nursing Press; 1991.

5. Muniz R, Zago M. A experiência da radioterapia oncológica para os pacientes: um remédio-veneno. Rev. Latino-Am. Enfermagem. 2008 novembro-dezembro; 16(6):998-1004.

6. Aquino $V$, Zago M. O significado das crenças religiosas para um grupo de pacientes oncológicos em reabilitação. Rev. LatinoAm. Enfermagem. 2007 janeiro-fevereiro; 15(1):42-7.

7. Vieira N, Vieira L, Frota M. Reflexão sobre a abordagem etnográfica em três pesquisas. Rev Latino-am Enfermagem. 2003 setembro-outubro; 11(5):658-63.

8. Ortner S. Theory in anthropology since the Sixties. Comparative Stud Soc History. 1984; 26(1):126-66.

9. Geertz C. A interpretação das culturas. Rio de Janeiro (RJ): Guanabara Koogan SA; 1989.

10. Laraia R. Cultura: um conceito antropológico. Rio de Janeiro(RJ): Zahar; 1986.

11. Mead M. Sex and temperament in three primitive societies. New York (NY): Morrow; 1935.

12. Butler J. Gender trouble: Feminism and the subversion of identity. New York (NY): Routledge, Champman \& Hall; 1990.
13. Campos MS. Poder, saúde e gosto. São Paulo (SP): Cortez; 1982.

14. Douglas M. Pureza e perigo. São Paulo (SP): Ed. Perspectiva; 1978.

15. Langdon EJ. Dados de pesquisa-de-campo entre os índios Barasana (1970). Mimeo; s/d.

16. Loyola A. Médicos e Curandeiros. São Paulo (SP): DIFEL; 1984.

17. Langdon EJ. Representações de doença e itinerário terapêutico entre os Siona da Amazônia colombiana. In: Santos RV, Carlos C, organizadores. Saúde e povos indígenas. Rio de Janeiro (RJ): Editora Fiocruz; 1994. p. 115-42.

18. Groisman A. Saúde, religião e corpo - seção temática. Ilha Rev Antropol. 2005 janeiro-dezembro; 7(1-2):111-62.

19. Garnelo L, Langdon EJ. A Antropologia e a reformulação das práticas sanitárias na atenção básica à saúde. In: Minayo MCS, Coimbra C, organizadores. Críticas e atuantes: ciências sociais e humanas em saúde na América Latina. Rio de Janeiro (RJ): Editora Fiocruz; 2005. p. 136-56.

20. Alves PC, Rabelo MC, organizadores. Antropologia da saúde: traçando identidades e explorando fronteiras. Rio de Janeiro (RJ): Relume Dumará/Editora Fiocruz; 1998.

21. Canesqui AM, organizadora. Ciências sociais e saúde para o ensino médico. São Paulo (SP): Hucitec/Fapesp; 2000.

22. Bonet $O$. Saber e sentir: uma etnografia da aprendizagem da biomedicina. Rio de Janeiro (RJ): Editora Fiocruz; 2004.

23. Tornquist CS. Paradoxos da humanização em uma maternidade no Brasil. Cad Saúde Pública 2003; 19(Suplemento 2):419-27. 